Compassionate
Communalism 



\title{
Compassionate Communalism
}

\author{
WELFARE AND \\ SECTARIANISM IN \\ LEBANON
}

Melani Cammett

Cornell University Press ITHACA AND LONDON 
Cornell University Press gratefully acknowledges receipt of a grant from the Watson Institute for International Studies at Brown University which aided in the publication of this book.

\section{Copyright ( 2014 by Cornell University}

All rights reserved. Except for brief quotations in a review, this book, or parts thereof, must not be reproduced in any form without permission in writing from the publisher. For information, address Cornell University Press, Sage House, 512 East State Street, Ithaca, New York 14850.

First published 2014 by Cornell University Press

First printing, Cornell Paperbacks, 2014

Printed in the United States of America

Library of Congress Cataloging-in-Publication Data

Cammett, Melani Claire, 1969- author.

Compassionate communalism : welfare and sectarianism in Lebanon /

Melani Cammett.

pages $\mathrm{cm}$

Includes bibliographical references and index.

ISBN 978-0-8014-5232-1 (cloth : alk. paper)

ISBN 978-0-8014-7893-2 (pbk. : alk. paper)

1. Charities-Lebanon. 2. Human services-Lebanon. 3. CommunalismLebanon. I. Title.

HV378.C36 2014

$361.7095692-\mathrm{dc} 23 \quad 2013040675$

Cornell University Press strives to use environmentally responsible suppliers and materials to the fullest extent possible in the publishing of its books. Such materials include vegetable-based, low-VOC inks and acid-free papers that are recycled, totally chlorine-free, or partly composed of nonwood fibers. For further information, visit our website at www.cornellpress.cornell.edu.
Cloth printing
109876554321
Paperback printing
10988766543321

Jacket photograph: A mobile clinic run by the Hezbollah (Party of God) offers free vaccination.Tebnine, Lebanon, 2004. Photo @ Abbas/Magnum Photos. 
For the people who shared their storiesmay their future be peaceful and secure. 
